\title{
The Best Evidence of the Effect of Products Liability Law on the Accident Rate: Reply
}

\author{
George L. Priest $\uparrow$
}

The differences between Professor Whitford's views ${ }^{1}$ and mine are of crucial importance to the law of products liability. Our objectives-indeed, the objectives of all interested in the field-are similar: to identify policies that, other things equal, will reduce the seriousness and frequency of injuries suffered by consumers. Professor Whitford and I differ sharply, however, in our predictions of the empirical effects of modern products liability policy. According to Professor Whitford, the policy adopted by courts over the last twenty years-the expansion of manufacturer liability beyond that undertaken in warranties-is likely to have reduced the rate of product defects. ${ }^{2}$ According to my investment theory, ${ }^{3}$ on the other hand, if consumer and manufacturer investments in safety are substitutes at the margin, the expansion of manufacturer liability is likely to have increased the rate of defects and the rate of consumer injuries. ${ }^{4}$ The vast number of product-related injuries compels us to examine these different implications very carefully. It is estimated that in 1977 alone, for example, consumers in the United States suffered 36 million product-related injuries. ${ }^{5}$

Professor Whitford's criticism of my article rests upon a misunderstanding of the nature of scientific reasoning. Whitford demands that my investment theory, as a "complete" theory, explain every phenomenon associated with product warranties and directly refute every conceivable alternative warranty theory. ${ }^{6}$ These requirements allow Whitford to confer

$\dagger$ Professor of Law, Yale University. I wish to thank Edward A. Dauer, Henry B. Hansmann, Jerry L. Mashaw, and Kenneth I. Wolpin for comments on various aspects of this response. Support for this paper was provided by the Civil Liability Program of Yale Law School for which I am very grateful. I am responsible for errors.

1. Whitford, Comment on a Theory of the Consumer Product Warranty, 91 Yale L.J. 1371 (1982) [hereinafter cited as Whitford].

2. Whitford at pp. 1372, 1385.

3. See generally Priest, $A$ Theory of the Consumer Product Warranty, 90 YALE L.J. 1297 (1981) [hereinafter cited by page number only].

4. Defects will increase because the expansion of manufacturer liability substitutes relatively more costly manufacturer investments in safety for less costly consumer investments in safety. See pp. 134751. The conditions under which such an effect will occur are quite general: when manufacturer and consumer investments are strong substitutes at the margin.

5. PROD. SAF. \& LIABIL. REP. (BNA) 511 (June 29, 1979) (reporting U.S. government estimate).

6. Whitford at pp. $1380,1384$. 
significance upon his assortment of "partial" theories, though he presents no evidence supporting any of them, and to dismiss the investment theory, though he acknowledges the substantial evidence supporting it. Whitford's typology of theories is unique, and his standard of scientific proof is unrealistic. I know of no scientific theory that has ever met such a standard, and doubt that any theory ever will. More importantly, however, Whitford's methodological strategem diverts attention from the empirical issue dividing us that ought to be the central focus of product liability reform: whether there is evidence that consumer and manufacturer investments in optimizing productive services are substitutes over the range relevant to legal liability. The answer to this question and to this question alone will determine whether modern developments in products liability law have increased or decreased the rate of product defects and injuries.

\section{Whitford's Criticism and Its Failing}

Whitford accepts the most important propositions of the investment theory. ${ }^{7} \mathrm{He}$ agrees that consumers invest in product care and the prevention of defects. ${ }^{8} \mathrm{He}$ agrees that warranties constitute a form of product insurance that pools consumers with different levels of risk.' Thus, he accepts the proposition that consumers whose expected losses are lower than average-such as the poor-are likely to prefer lower levels of warranty insurance. ${ }^{10}$ It follows simply that mandatory insurance is redistributive and, with respect to the poor, regressively redistributive. ${ }^{11}$ Furthermore, Whitford generously regards my investment theory explanations of differences in warranty terms among products as "on the whole plausible."12 Indeed, Whitford concludes-though I had regarded the suggestion as tentative $\mathrm{e}^{13}$-that consumer preferences influence warranty terms both through the efforts of a set of informed shoppers ${ }^{14}$ and through repeat purchase decisions. ${ }^{15}$

Whitford's objection, however, is that the investment theory does not explain all phenomena related to product warranties. There exist other theories, not intuitively implausible, that might explain other warranty

7. Indeed, Whitford claims that he first formulated the investment theory. Whitford at p. 1375 \& n.20. I will concede to Professor Whitford the originality of the investment theory if, after this exchange, he accepts its implications.

8. Id. at pp. $1371,1377$.

9. Id. at pp. 1377-78 \& nn.28, 33, 36.

10. Id. at nn.33, 36 .

11. See id. Professor Whitford qualifies this conclusion, correctly, for products purchased solely by the poor.

12. Id. at pp. 1377.

13. Pp. 1346-47.

14. Whitford at pp. 1377, 1384.

15. Id. 
practices. ${ }^{16}$ Whitford presents no new evidence supporting these theories, nor does he attempt to reinterpret more than small bits of my data as consistent with them. Instead, Whitford maintains that unless I can directly refute each of these "partial" theories, the investment theory, as a "complete" theory, fails and can be rejected. ${ }^{17}$ Whitford knows that there are no available data that bear directly on some of these theories-for example, data on the frequency of social contacts between the sales and law departments of particular manufacturers, the level of education of buyers of particular products, or the intensity with which corporate managers fear warranty regulation. ${ }^{18}$ Whitford seems to believe that without such data I cannot challenge these partial theories. ${ }^{19}$ Thus, Whitford dismisses the investment theory. ${ }^{20}$

Whitford misconceives the nature of scientific inquiry. All scientific theories are abstractions and thus are necessarily "partial" rather than "complete." ${ }^{21}$ The only question is whether a theory is a relevant abstraction. ${ }^{22}$ A theory relevant to the evaluation of products liability law must address the determinants of product safety. There are many practices related to product warranties that have no influence on product safety and, thus, for this purpose, can be ignored. I believe-and I shall explain why below-that the investment theory identifies the principal determinants of product safety. If it does, then the investment theory can predict the effects of a change in the law on the rate of accidents, even though Whitford can identify other factors related to warranty content that the investment theory does not explain.

Professor Whitford's "social contacts" theory illustrates his lack of sensitivity to this point. One of Whitford's "partial" theories, said to refute the investment theory, is that differences in warranty provisions result from different "personal relationships" among the members of a firm's sales department or its chief executive officer and its lawyers..$^{23}$ It is not implausible as a general matter that social and professional relationships within a firm affect to some extent the firm's policies and decisions. Such relationships, for example, might reduce the cost of transferring information between one division and another or may make the firm's policies and

16. Id. at p. 1380 .

17. Id. at pp. 1378-79, 1380.

18. Id. at pp. $1380-83$.

19. Id. at p. 1384 (by inference). Whitford's discussion of his various partial theories makes no reference to the relevant data contained in my article. Id. at pp. 1380-84.

20. Id. at p. 1384-85.

21. See generally T. KUHN, THE STRUCTURE OF SCIENTIFIC REVOLUTIONS (1962); Kuhn, The Function of Measurement in Modern Physical Science, in THE EssENTUL TENSION 178 (1977); Friedman, The Methodology of Positive Economics, in EsSAYs IN POSITIVE EcONOMICS 3 (1953).

22. See Kuhn, The Function of Measurement in Modern Physical Science, supra note 21, at 178.

23. Whitford at pp. 1381-82. 
activities more coherent or uniform. ${ }^{24}$

The important question for social policy, however, is whether social contacts within a firm significantly influence product safety. Most people believe that the rate of product defects is more substantially influenced by legal rules that define the responsibilities of manufacturers for productrelated losses than by the extent to which the firm's officers are "close socially." Thus, individuals concerned about product injuries have tended to concentrate their efforts on law reform rather than, say, on the fostering of more congenial social atmospheres within firms. In other words, the vast majority of commentators have regarded "personal relationships," however important to the explanation of other behavior of the firm, as irrelevant to the rate of product injuries. Of course, these commentators (including myself) may be wrong. Yet I know of no studies relating product injuries to social contacts. And Whitford presents no evidence supporting the social contacts theory, ${ }^{25}$ or even supporting his view that social contacts are empirically relevant to the rate of product defects. The "social contacts" theory is no more than a hunch. ${ }^{26}$

Professor Whitford's other partial theories are subject to a similar objection. Whitford discusses these theories only in terms of their intuitive plausibility and the evidence necessary to directly test them. ${ }^{27}$ All must agree with Whitford that these theories possess some degree of plausibility. But according to Whitford's view of scientific method, such a concession amounts to a complete victory for his approach. To Whitford, a partial theory with no more than an air of plausibility and an absence of direct refutation defeats what he calls a "complete" theory. ${ }^{28}$ This explains why Whitford devotes such substantial effort to characterizing the investment theory as "complete"29 (although sometimes he hedges, calling it "predominant" or more comprehensive)..$^{30}$ This standard is unknown to

24. These explanations, incidentally, in no way undermine the cost-based investment theory.

25. Whitford does claim that warranty provisions disclaiming personal injury liability in legal regimes in which such disclaimers are unenforceable may reflect the influence of social contacts. Whitford at pp. 1381-82. There were no such provisions in the warranties of my sample, however. Whitford also asserts that the exclusion of consequential damages in dryer warranties, but not in range warranties, may be explained by the organizational structure of manufacturers. Id. at p. 1381. Whitford presents no evidence supporting this assertion. A more likely (but equally hypothetical) explanation, consistent with the investment theory, is that the dryer exclusion is intended to deny recovery for heat damage to clothing, particularly synthetics. More careful consumers may not want coverage of such losses. There is no clearly comparable property damage from excessive range heat; personal injury losses, of course, are non-excludable.

26. The implications of the social contacts theory are unclear. Are firms with closer social contacts expected to offer more generous warranties, or less safe products, or simply more legalistic warranties?

27. See Whitford at pp. 1378-84.

28. Id. at pp. $1380-81$ (by inference); p. 1384.

29. Id. at pp. $1374-76$ \& n. 19 .

30. Id. at p. $1376 \&$ n.23. 
modern science. Was Darwin ever able to refute the theory of the divine origin of species?

Grappling with a typology of theories misses the point. The only useful way to evaluate a theory is to confront it with evidence. ${ }^{31}$ Thus, the only issue relevant to products liability policy is whether the investment theory or any other theory (including those of Professor Whitford) best explains the available evidence of the determinants of product safety. My article presents data, which had not been previously available, of the product defect policies embodied in the warranties of individual firms in a wide set of consumer product industries. ${ }^{32}$ These warranties define the legal obligations of manufacturers and consumers in the event of product loss. Although they provide no direct evidence of the accident rate, they do indicate how manufacturers and consumers allocate responsibility between themselves for the prevention of defects and injuries, which is inferential evidence of the determinants of the accident rate. Currently, there is no direct evidence of the effect of products liability law on the accident rate and there is no better data of the determinants of product safety. Thus, the data in my article provide our best current opportunity to address this important question of public policy.

Furthermore, these data are sufficiently detailed to test Professor Whitford's theories. Professor Whitford seems to believe that his theories can only be refuted with direct evidence, such as evidence of the level of buyer education or of manufacturer fear of regulation. Whitford, however, has not examined the data in my article with adequate care. The article includes substantial evidence bearing on Whitford's theories. What does the evidence show?

\section{The Theories and the Evidence Supporting Them}

In my view, the data presented in my article suggest strongly that manufacturer and consumer investments in productive services are substitutes at the margin and that warranty provisions are designed to influence the level of care that manufacturers and consumers invest in products. Professor Whitford does not contest or attempt to reinterpret the vast bulk of these data. For example, parts provisions in warranties place liability on consumers by limiting coverage of or excluding liability for parts that are

31. This assumes only that the theory has testable implications-a theory without such implications is no theory at all.

32. I surveyed the warranties of $\mathbf{1 6}$ product groups: cookware, refrigerators, freezers, gas ranges, electric ranges, washers, dryers, air conditioners, color televisions, stereos, automobiles, recreational vehicles, coaches, truck mounts, travel trailers, and mobile homes. The warranties were provided by the Federal Trade Commission. See pp. 1319-20 \& n.109 for further description of the data. 
most vulnerable to rough or careless consumer use. ${ }^{33}$ Other parts provisions place liability on manufacturers by granting coverage more extensive than normal for parts whose performance seems affected primarily by manufacturer investments, parts that are inaccessible to consumers and least likely to be affected by consumer use. ${ }^{34}$ Many warranties exclude coverage of losses from consumer behavior that subjects a product to a higher likelihood of damage (such as the use of a recreational vehicle by a club or group, hauling trailers or heavy loads, high speed acceleration or gear-shifting). ${ }^{35}$ The duration of warranty coverage, disclaimers of merchantability and exclusions of consequential damages are correlated with these specific provisions, further suggesting variations among consumers in their use and care of these products. ${ }^{36}$

Again, for the most part, Professor Whitford does not contest the investment theory interpretation of these data. Instead, he defends two theories that my article shows as explaining very little, and proposes four new additional theories of warranty behavior. Let us inquire-as Whitford might have done-whether his theories can explain consistently the phenomena within their scope.

\section{A. Whitford's Consumer Misperception Theories}

Three theories that Whitford defends-two new theories and the signal theory that my article examines-address the influence of consumer demand on warranty coverage, in particular, the influence of consumer perceptions. One of Whitford's theories predicts that products sold to consumers with less education or less experience will provide less extensive warranty coverage, a theory that Whitford views as consistent with findings that the poor pay higher prices for products than the middle class. ${ }^{37}$ A second of Whitford's theories proposes that warranty content is affected by consumer decisions that "overdiscount long-term risks." ${ }^{38}$ Possibly Whitford means that consumers are risk-preferrers. ${ }^{39} \mathrm{~A}$ more attractive way of putting the point is that consumers fail to understand or to calcu-

33. Pp. 1328-30.

34. Pp. 1330-31. According to the theory, consumers may affect parts indirectly by the volume and intensity of their use of the product. Pp. 1315-16. Thus, the theory explains why parts shielded from direct consumer contact are nonetheless warranted for periods much less than the average expected service life. P. 1327 \& Table 4; see also infra p. 1395.

35. Pp. 1333-35. It is less clear under the law than under the warranty whether such uses are reasonable, contrary to Professor Whitford's suggestion that the law efficiently precludes recovery unless the product is "defective." Whitford at p. 1385.

36. Pp. 1343-46.

37. Whitford at pp. 1380-81 Professor Whitford acknowledges that modern research on relative prices to the poor explains observed price differentials in terms of real distribution costs.

38. Id. at p. 1384.

39. For a similar argument, see R. POSNER, ECONOMIC ANALYSIS OF LAW 135-37 (1977). 
late properly long-term risks, and consequently they demand less warranty coverage than they would if they were fully informed. ${ }^{40}$

The signal theory is a more general statement of the same approach. Because information about product quality is costly to obtain, consumers are never fully informed. Warranties lower the information costs of product quality, and hence warranty terms ought to be correlated with the quality of underlying product characteristics. ${ }^{41}$ Whitford's two theories obviously are only special cases of the signal theory addressing particular sources of costly information although, perhaps, suggesting different correlations between product quality and warranty content.

It is certainly plausible a priori that some consumers have difficulty evaluating long-term risks and obtaining information about product durability, and that some consumers, of course, are poorly educated. It is also plausible that such deficiencies may influence the extent to which such consumers consider and understand warranty terms when making their purchases. Indeed, my article suggests that consumer information costs account for the existence of warranties, ${ }^{42}$ although these costs do not explain differences among products in warranty terms. The crucial question for public policy, however, is whether information deficiencies of this nature are important at the margin. That is, are information deficiencies important determinants of how manufacturers and consumers allocate responsibility for safety-related precautions?

The article presents three types of evidence relevant to this question, each based on variations in the provisions of the sample warranties. The data reveal variations in the content of warranties of different products, in the treatment of different characteristics of the same product, and in the relationship between warranty content and measures of product durability. These variations indicate different ways that firms allocate responsibility between manufacturers and consumers for safety-related precautions. Thus, if information deficiencies are determinants of these allocations, the observed variations ought to be related in some consistent way to information deficiencies. Whitford insists, of course, that no single hypothesis of his (as opposed to, of mine) must explain all warranty variations, ${ }^{43}$ and I will accept his standard for now. Surely, however, it is fair to insist, once the specific information deficiency is defined, that for each hypothesis one should observe consistent results for those aspects of the

40. This interpretation is preferable because it avoids the problems of paternalism.

41. Pp. 1303-07 (further discussion of implications and evidence supporting signal theory).

42. Pp. 1309-10. I describe warranties as providing a performance bond of the manufacturer equal to the value of expected repair costs during the warranty period. Consumers demand a performance bond because prior to purchase they cannot costlessly obtain information about the durability and reliability of the product.

43. Whitford at pp. 1380, 1384. 
warranties or of the products themselves that fall within the scope of the deficiency.

Table 1 rank orders the different products of the sample according to the principal provisions of their warranties (most generous at the top, least generous at the bottom). Column (1) shows that warranty duration is longer for freezers, air conditioners, washers, and refrigerators than for dryers, color televisions, electric and gas ranges and automobiles (in that order). Column (2) indicates the extent to which the different product warranties incorporate the principal exclusions: the disclaimer of merchantability, the exclusion of consequential damages and the limitation of coverage to the original purchaser. Column (3) shows the proportion of warranties that exclude transport costs, a provision that Professor Whitford believes is particularly reflective of information deficiencies. ${ }^{44}$

Table 1: Warranty Provisions by Product, 1974,

Rank Ordered (most generous at top)

\begin{tabular}{|c|c|c|c|}
\hline $\begin{array}{c}(1) \\
\text { Duration } \\
\text { Warranty } \\
\text { Coverage in } \\
\text { years* } \\
\text { (Basic/Extended) }\end{array}$ & $\begin{array}{c}(2) \\
\text { Exclusions } \\
\text { (merchantability, } \\
\text { conseq. damages, } \\
\text { orig. purchaser) }{ }^{* *} \\
\text { (\% of firms) }\end{array}$ & $\begin{array}{c}\text { (3) } \\
\text { Transport } \\
\text { Cost } \\
\text { Exclusion** } \\
\text { (\% of } \\
\text { firms) }\end{array}$ & $\begin{array}{l}\text { (4) } \\
\text { Service-Life } \\
\text { Expectancy } \\
\text { for First } \\
\text { Owner*** } \\
\text { (years) }\end{array}$ \\
\hline $\begin{array}{l}\text { Freezers } \\
\qquad(5 / 5)\end{array}$ & $\begin{array}{c}\text { Freezers } \\
(0,0,0)\end{array}$ & $\begin{array}{c}\text { Gas Ranges } \\
(0)\end{array}$ & $\begin{array}{c}\text { Freezers } \\
20.4\end{array}$ \\
\hline $\begin{array}{l}\text { Air Conditioners } \\
(3 / 5)\end{array}$ & $\begin{array}{c}\text { Elec. Ranges } \\
(0,0,25)\end{array}$ & $\begin{array}{l}\text { Washers } \\
\text { (20) }\end{array}$ & $\begin{array}{c}\text { Refrigerators } \\
15.2\end{array}$ \\
\hline $\begin{array}{l}\text { Washers } \\
(1,2 / 5)\end{array}$ & $\begin{array}{l}\text { Washers } \\
(0,0,40)\end{array}$ & $\begin{array}{l}\text { Elec. Ranges } \\
\text { (25) }\end{array}$ & $\begin{array}{c}\text { Dryers } \\
13.7\end{array}$ \\
\hline $\begin{array}{c}\text { Refrigerators } \\
(1,5 / 5)\end{array}$ & $\begin{array}{c}\text { Gas Ranges } \\
(0,0,50)\end{array}$ & $\begin{array}{c}\text { Color TVs } \\
\text { (33) }\end{array}$ & $\begin{array}{c}\text { Gas Ranges } \\
13.5\end{array}$ \\
\hline $\begin{array}{l}\text { Dryers } \\
(1 / 2,5)\end{array}$ & $\begin{array}{c}\text { Color TVs } \\
(0,0,66)\end{array}$ & $\begin{array}{l}\text { Dryers } \\
(50)\end{array}$ & $\begin{array}{c}\text { Elec. Ranges } \\
12.1\end{array}$ \\
\hline $\begin{array}{l}\text { Color TVs } \\
(1 / 2)\end{array}$ & $\begin{array}{c}\text { Refrigerators } \\
(20,20,20)\end{array}$ & $\begin{array}{l}\text { Air Conditioners } \\
(50)\end{array}$ & $\begin{array}{c}\text { Color TVs } \\
12.0\end{array}$ \\
\hline $\begin{array}{c}\text { Elec. Ranges } \\
(1 / 0,3)\end{array}$ & $\begin{array}{l}\text { Air Conditioners } \\
\quad(20,20,40)\end{array}$ & $\begin{array}{c}\text { Refrigerators } \\
(60)\end{array}$ & $\begin{array}{c}\text { Washers } \\
10.8\end{array}$ \\
\hline $\begin{array}{c}\text { Gas Ranges } \\
(1 / 0)\end{array}$ & $\begin{array}{c}\text { Automobiles } \\
(75,75,0)\end{array}$ & $\begin{array}{l}\text { Automobiles } \\
\text { (75) }\end{array}$ & $\begin{array}{c}\text { Automobiles } \\
9.4\end{array}$ \\
\hline $\begin{array}{c}\text { Automobiles } \\
(1 / 0)\end{array}$ & $\begin{array}{c}\text { Dryers } \\
(100,100,100)\end{array}$ & $\begin{array}{c}\text { Freezers } \\
(100)\end{array}$ & \\
\hline
\end{tabular}

Sources:

* Priest, Consumer Product Warranty at 1327, Table 4 and 1341, Table 7.

* Id. at 1325, Table 3.

*** Id. at 1341, Table 7.

44. Id. at p. 1378. 
According to Whitford's misperception hypotheses, the differences in the warranty provisions of these products may be related to the level of consumer education, to the propensity of consumers to overdiscount risks or to the general costliness of information. Are any of these hypotheses plausible? Table 1 shows great inconsistency in the relative generosity of the warranty provisions of individual products. Only automobile warranties appear in a consistent position on the lists (near the bottom), suggesting under Whitford's misperception theories that automobile purchasers are relatively less educated or informed. ${ }^{45}$ To be fair to Professor Whitford, his theories allow for the possibility that consumers have more information about some warranty provisions than others. But to accept even this (nearly tautological) version of the misperception hypotheses, it is necessary to believe, for example, that consumers of freezers are well educated or informed about the duration of coverage and the general exclusions, but poorly educated or informed about the transport exclusion. In contrast, consumers of gas ranges must be poorly educated or informed about the duration of coverage, but well educated or informed about exclusions, particularly the transport exclusion. Purchasers of dryers must be educated or informed at the middle range about warranty duration and transport costs, but poorly educated or informed about the general exclusions. Unfortunately, these propositions collectively seem contradictory.

The sample warranties also show variations in the coverage of different product characteristics. Some product parts, for example, are given extended warranty coverage; other parts are excluded from coverage. Is this evidence consistent with any of the misperception hypotheses? To accept the misperception hypotheses it would be necessary to believe, for example, that consumers of refrigerators, freezers or air conditioners are well educated or informed about the compressor and sealed refrigeration systems of these products (for which five-year coverage is typically offered), but poorly educated or informed about the exterior finish, plastic parts, gasket and fuses (which, typically, are excluded from coverage). Similarly, purchasers of washing machines would have to be well educated or informed about the product's transmission (typically, five-year coverage), but poorly educated or informed about light bulbs and porcelain (typically, excluded). Oddly, these propositions suggest that consumers are better educated or informed about the internal mechanical parts of these products than about the exterior parts obvious to any inspection. This is a

45. According to the investment theory, on the other hand, automobile warranties are shorter in duration and incorporate a greater number of exclusions because of greater differences between automobile consumers in terms of the uses to which they put the product or the damages that they might suffer, See pp. 1333, 1334, 1338, 1345-46. 
very peculiar form of information deficiency. ${ }^{46}$

The evidence most difficult to reconcile with the consumer misperception hypotheses, however, is the relationship between basic warranty coverage (column (1)) and service-life expectancy (column (4)). My article demonstrates that there is no clear correspondence between warranty duration and service-life expectancy, ${ }^{47}$ as clear a refutation as is possible of the one central implication of the signal theory. Professor Whitford ignores this evidence, ${ }^{48}$ but it is equally damaging to his various misperception theories. Is it plausible that purchasers of automobiles overdiscount the risk of future repairs to demand one year of warranty coverage, but properly discount auto durability to demand 9.4 years of service-life? Are consumers of refrigerators so poorly educated or informed about warranties as to be given only one-or five-year coverage, but so well educated or informed about product durability that manufacturers must give them a machine that operates for 15.2 years? The disparity between basic warranty coverage and service-life expectancy is equally extreme for the other products: gas ranges-1-year warranty, 13.5 year service-life; dryers-1year warranty, 13.7 year service-life; color televisions-1-year warranty, 12.0 year service-life; freezers-5-year warranty, 20.4 year service-life. These differences cannot be explained by differential perceptions, education or experience. ${ }^{49}$ The perceptions of consumers of the need for future product repair and their perceptions of product service-life must be very closely related. To explain the data, Professor Whitford would have to claim that there are separate and independent determinants of each set of perceptions.

Whitford repeatedly insists that his theories are "partial" and must not be called upon to explain every observation. But a credible hypothesis

46. According to the investment theory, parts excluded from coverage tend to be those either easily breakable or sensitive to different treatment by consumers. Parts given extended coverage are those housed deep within the product, often protected by padding and bracing, and thus less susceptible to damage from rough handling short of misuse. See pp. 1329-31.

47. Pp. at 1326-27.

48. Indeed, Professor Whitford grossly misinterprets my findings when he states that my data "offer significant support for the principal hypothesis of signal theory." Whitford at p. 1379. Here Whitford refers to the post hoc signal theory implication of uniform one-year warranty coverage. The page to which Whitford refers for the theory's "substantial support" reads: "The warranties of my sample show substantial variation from the uniformity predicted by the signal theory." P. 1339. At this sentence I describe findings showing that one-year coverage of all parts and labor expenses is offered by only 12 of 62 sample warranties: 9 automobile warranties, 1 appliance warranty, and 2 mobile home warranties. P. 1339 n.175.

49. The disparity between warranty coverage and service-life expectancy provides strong support for the investment theory. Warranty coverage expires when differences among consumers in their investments to prolong product life become significant. Thus, low-risk consumers find longer coverage worth less than its average cost and are sufficient in number to dominate the warranty market. The disparity supports the proposition that manufacturer and consumer investments are strong substitutes at the margin. See supra note 4. I know of no other theory, however partial, that can coherently explain this disparity. See infra pp. 1399-1400. 
must explain some set of observations consistently. ${ }^{50}$ However plausible the general notion that consumers are poorly informed, is there reason to believe that for some products they are less informed about the exclusion of consequential damages than about the exclusion of transport costs; that consumers are ignorant with respect to warranty coverage but sophisticated with respect to product durability? It seems impossible to define a credible set of consumer perceptions that explains the variations in warranty coverage in Table 1 . Whitford rests on individual examples-the exclusion of transport charges seen in one set of product warranties, ${ }^{51}$ the disclaimer of merchantability seen in another set ${ }^{52}$ - which he claims may relate to information deficiencies. But the modesty of Whitford's claims cannot justify a promiscuous selection from among the data.

\section{B. Whitford's Market Power Theories}

Whitford's final two theories address the relationship between warranty content and manufacturers' bargaining power. My article found little evidence in support of the exploitation theory, according to which manufacturers exercise bargaining power superior to consumers by offering onesided warranties. ${ }^{53}$ Whitford defends the exploitation theory by accusing me of misrepresenting it. ${ }^{54} \mathrm{He}$ also suggests an alternative market power hypothesis that turns the exploitation theory on its head. Whitford emphasizes that at the time the warranties in my sample were issued, Congress was considering warranty regulation. According to Whitford, firms in concentrated industries-the automobile manufacturers in particular-were likely to have been fearful of government regulation of their warranties, and thus may have offered relatively more generous warranty coverage than firms in unconcentrated industries. ${ }^{55}$

Let me first address the fear-of-regulation theory. Whitford is certainly correct that in 1974, when the sample warranties were issued, Congress had before it the Magnuson-Moss Warranty Act, which it enacted in $1975 .^{56}$ Whitford is also correct that automobile warranties were a special focus of the hearings and studies commissioned by Congress prior to enactment. ${ }^{57}$ Whitford's history, however, is incomplete. ${ }^{58}$ Congress had con-

50. Indeed, to avoid tautology, a credible "partial" theory must provide a coherent explanation of why it addresses only some portion of the observed phenomena. None of Whitford's partial theories meet this standard.

51. Whitford at p. 1378.

52. Id. at $\mathrm{pp}$. 1381-82.

53. Pp. 1290-1302, 1320-25.

54. Whitford at p. 1379 \& nn.20, 30.

55. Id. at p. 1383.

56. 15 U.S.C. $\$ \$ 2301-2312$ (1976).

57. See FEDERAL TRADE COMMISSION, STAFF REPORT ON AUTOMOBILE WARRANTIES (1970).

58. For an extended discussion of the Act's history, see Priest, The Regulation of Product War- 
sidered warranty bills indistinguishable in substance from the MagnusonMoss Act since 1967.59 Professor Whitford acknowledges that the Magnuson-Moss Act does not incorporate substantive regulation of warranty content to any great extent; ${ }^{60}$ neither did any of the earlier bills. ${ }^{61}$ Thus, what had the manufacturers to fear? Further, automobile warranties were only one of the subjects of particular congressional concern. Senator Magnuson's 1967 bill applied not only to the warranties of the highly concentrated automobile industry, but also to the warranties of the various appliance groups, ${ }^{62}$ which are either moderately concentrated or unconcentrated. More generally, Whitford does not explain why a single firm would sacrifice profits by offering an excessively generous warranty to protect the future returns of other firms and industries (including its competitors) potentially subject to the regulation. A concerted agreement to offer excessive coverage would seem necessary.

Let us, however, put aside these questions about the plausibility of Whitford's theory and look to the evidence. Unfortunately, the evidence does not show that the more concentrated industries offer the more generous warranties. ${ }^{63}$ It shows that there is no clear relationship of any kind between warranty content and either industry concentration or firm market share. ${ }^{64}$ Thus, there is no more evidence for the hypothesis that concentrated industries offer relatively greater coverage than for the conflicting exploitation hypothesis that firms with greater market power ${ }^{65}$ offer relatively lower coverage.

Furthermore, there is no support for. Whitford's more specific assertions. Whitford predicts that automobile warranties will be more generous than average because they were the subject of special congressional scru-

ranties under the Magnuson-Moss Warranty Act (unpublished manuscript on file with Yale Law Journal), reprinted in part in Priest, The Structure and Operation of the Magnuson-Moss Warranty Act, in THE FEDERAL TRADE COMMISSION SINCE 1970 at 246 (Clarkson \& Muris eds. 1980).

59. See S. 2726-28, 90th Cong., 1st Sess., 113 CONG. REC. 35,278-84 (1967). A revised version of Senator Magnuson's 1967 bill was passed by the Senate in 1970, S. 3074, 91st Cong., 2nd Sess., 116 CONG. REC. 22,487 (1970), and again in 1971, S. 986, 92nd Cong., 1st Sess., 117 CoNG. REC. 39,876 (1971), although it failed to gain House approval both times. Congressional support for some federal legislation, however, was strong. The 1971 version of the Senate bill passed by a vote of 72-2. Id.

60. Whitford at p. 1382 n.40. I have shown the minimal effect of the Act on product warranties in Priest, The Structure and Operation of the Magnuson-Moss Warranty Act, supra note 58.

61. See Priest, The Regulation of Product Warranties under the Magnuson-Moss Warranty Act, supra note 58 , at 3 .

62. See supra note 59 .

63. A study cited by Whitford claims to show that larger firms offer more generous warranties. This inference, however, is inappropriate because the study measures firm size by dollar sales volume. Thus, a firm that sells one $\$ 8000$ mobile home appears "larger" than a firm that sells forty $\$ 195$ televisions. Obviously, more careful measure of relative sizes within industries is necessary. See Note, An Empirical Study of the Magnuson-Moss Warranty Act, 31 STAN. L. REV. 1117 (1979).

64. Pp. 1321-25 \& Tables 1-3.

65. See infra pp. 1399-1400 (definition of market power). 
tiny. ${ }^{66}$ Table 1 shows that the automobile warranties in 1974 were among the least generous in coverage. Of course, fear is a subjective response. But to accept Whitford's theory one must believe that manufacturers in each of the seven product groups ${ }^{67}$ listed in Table 1 plus two additional product groups discussed in the article ${ }^{68}$ were more fearful of warranty regulation than the auto manufacturers, even though the concentration level of each of these nine industries was significantly lower than that of the automobile industry. ${ }^{69}$

An additional datum: one group of manufacturers whose warranties were studied in the article-the mobile home manufacturers-had special reason to fear warranty regulation in 1974 . The Federal Trade Commission began an investigation of mobile home warranty practices in $1972 .^{70}$ In 1974, when my sample warranties were issued, four major mobile home manufacturers had been threatened with actions under section 5 of the Federal Trade Commission Act. ${ }^{71}$ In addition, the Commission's Bureau of Consumer Protection was in the process of drafting a report of its investigation. Consent decrees were entered in each of the four actions in March, 1975,72 and the Bureau issued its final report in November, $1975 .{ }^{73}$ The report excoriated the mobile home industry for its exploitative warranty behavior and proposed a Trade Regulation Rule subjecting mobile home manufacturers to detailed substantive regulation of warranty performance. ${ }^{74}$ The regulations proposed in the Trade Rule are far more detailed and intrusive than those of the Magnuson-Moss Act. Is there evidence of fear in mobile home warranties? Unfortunately for Professor Whitford's hypothesis, mobile home warranties are among the least generous of the sample in terms of both duration of coverage and exclusions. They are only slightly more generous than the auto warranties. ${ }^{75}$

66. Whitford at $\mathbf{n . 4 0}$.

67. I count only 7 rather than 8 product groups in Table 1 on the assumption of a relatively high cross-elasticity of demand between electric and gas ranges. In $\mathrm{my}$ article I treated electric and gas ranges as separate markets to err in favor of the exploitation theory. Pp. 1322 (Table 1), 1323 (Table 2), \& 1325 (Table 3).

68. Mobile homes and travel trailers. See p. 1325 (Table 3).

69. In 1974 the four-firm concentration ratio for automobiles was $100 \%$; gas ranges $75 \%$; washers, 73\%; electric ranges, $73 \%$; dryers, $73 \%$; refrigerators, $72 \%$; freezers, $71 \%$; color televisions, $60 \%$; air conditioners, $59 \%$; travel trailers, $33 \%$; mobile homes, $29 \%$. Id.

70. See De Alessi, Regulating Post Purchase Regulations: Mobile Homes, in THE Federal TRADE COMMISSION SINCE 1970, at 204 (Clarkson \& Muris eds. 1980).

71. Federal Trade Commission Act, 15 U.S.C. § 45 (1976).

72. Redman Indus., 85 F.T.C. 309 (1975); Fleetwood Enterprises, 85 F.T.C. 414 (1975); Skyline Corp., 85 F.T.C. 444 (1975); Commodore Corp., 85 F.T.C. 472 (1975).

73. Staff Statement of Position, Proposed Trade Regulation Rule Regarding Mobile Home Sales and Service, Federal Trade Commission (Nov. 11, 1975), cited in De Alessi, supra note 70, at 347 n.4.

74. Proposed Trade Regulation Rule, Mobile Home Sales and Service, 40 Fed. Reg. 23,334-40 (1977).

75. P. 1325 (Table 3). According to the investment theory, mobile home warranties offer rela* 
Finally, Whitford defends the authors of the exploitation theory, which provides that manufacturers will exercise superior bargaining power by drafting one-sided warranties. My article challenges this theory by showing that there is no relationship between warranty content and market power measured in two separate ways: individual firm market share, and industry concentration. ${ }^{76}$ Whitford does not reinterpret my data or report new data. ${ }^{77}$ Instead, Whitford accuses me of misinterpreting the work of the exploitation theorists. None of those theorists, Whitford asserts, explicitly claim a precise relationship between warranty content and either market share or concentration. ${ }^{78}$

Here, I suppose, Whitford is right. None of the exploitation theorists did define a clear relationship between market share and warranty content. The discussion in the exploitation literature of market power or bargaining power was (and remains today ${ }^{79}$ ) impressionistic and imprecise. ${ }^{80}$ The exploitation theorists assert unmistakably that manufacturers exploit superior bargaining power. ${ }^{81} \mathrm{I}$ attempted, as fairly as I could, to introduce some rigor to such statements in order to generate implications that would allow the theory to be tested. The implications are straightforward. Market share and industry concentration are common and widely accepted measures of market power in the context of antitrust law. ${ }^{82}$ Are there better (non-tautological) measures of market power?

Whitford's dismay over the use of such measures, however, can be readily appreciated. Most of us, I would imagine, share some intuitive feeling that manufacturers possess bargaining power superior to any consumer and that consumers have few opportunities to choose among warranty terms. This feeling accounts, I believe, for the popularity of the contractof-adhesion and unfair bargaining power concepts in modern jurisprudence. When the intuition is restated rigorously, however-as a relationship between market share or industry concentration and warranty content-its imprecision becomes more obvious. Market share and concentration suggest the importance of general competitive conditions, which certainly differ among industries. Our intuitions, in contrast, do not

tively limited coverage because mobile homes, like automobiles, are susceptible to widely different uses by consumers. Thus, consumers who use mobile homes relatively less intensively demand lower warranty coverage.

76. Pp. 1320-25.

77. Whitford restates the exploitation hypothesis in terms of the lack of consumer information. Whitford at pp. 1380, 1384. I have addressed this theory above. See supra pp. 1393-1396.

78. Id. at p. 1378 \& nn.20, 29, 32.

79. See, e.g., Slawson, Mass Contracts: Lawful Fraud in California, 48 S. CAL. L. REV. 1 (1974) (modern version of exploitation idea).

80. See pp. 1299-1302 (discussing exploitation literature).

81. Whitford himself discusses the authorities who make this suggestion. Whitford at p. 1378 n.29. I discuss the exploitation literature at pp. 1299-1302.

82. I present both four-firm and Herfindahl index measures. Pp. 1322-25 (Tables 1-3). 
commonly incorporate a concentration index. In addition, the more careful definition of the problem raises questions of industrial behavior: Why does the offer of one-sided warranty terms generate greater profits than a monopoly price? What is the relationship between a manufacturer's investment in warranty coverage and its investment in other product characteristics? Why does a manufacturer that possesses superior bargaining power offer an exploitative warranty while providing a product with a 13- to 15year service-life expectancy? Questions of this nature are routine in antitrust analysis (perhaps because it builds upon a stronger empirical base), but virtually unknown in contracts or products liability law although the underlying issues are the same. ${ }^{83}$ The exploitation theory of warranties does not and, I believe, cannot answer these questions.

If I have distorted the approach of the exploitation theorists, it is "distortion" that comes from the sharpened focus of any careful, scientific study. Upon closer view, a flat world becomes round, and the Martian canals are shown to be illusions. The brilliant and moving calls of Professor Kessler in 1943 and of Professor Leff in $1970^{84}$ to the attack on incompletely bargained contracts provoked sympathy in many of us in the contracts field. Their ideas have dominated our thinking about contractual relations, especially between manufacturer and consumer, and have transformed the law of products liability ${ }^{85}$ Unfortunately, the suppositions upon which their ideas are based are unsupported by the evidence. The time has come for a new view of the world.

\section{The Most Informed Judgment of the Effects of Products Liability} Law

In my view, given the evidence available of the determinants of product safety, the expansion of manufacturer liability for product defects ${ }^{86}$ has

83. But see Trebilcock, The Doctrine of Inequality of Bargaining Power. Post-Benthamite Economics in the House of Lords, 26 U. TORONTO L.J. 359 (1976). Another example of unfamiliarity with simple ideas of industrial organization is Professor Whitford's discussion of warranties as barricrs to entry. Whitford at p. 1383. Virtually all discussions of barriers to entry focus upon different opportunities (costs, profits) between entering firms and firms currently in the market. Sec J. BAIN, BARRIERS TO NEW COMPETITION 5 (1956); Demsetz, Barriers to Entry, 72 AM. ECON. REV. 47 (1981). The barrier identified by Professor Whitford-generous warranty coverage offered by current firms which must be matched by entering firms-does not suggest either a differential cost or profit and would not qualify as a barrier to entry under the common definition.

84. Kessler, Contracts of Adhesion-Some Thoughts about Freedom of Contract, 43 CoLUM. L. REv. 629 (1943); Leff, Contract as Thing, 19 AM. U.L. REv. 131 (1970).

85. See pp. 1299-1302.

86. Whitford also complains that I misunderstand the law of products liability. He emphasizes that a court may define "defect" and the "cause" of an injury in a manner that incorporates "leastcost avoider" concepts. Whitford at pp. 1376, 1385. Thus, Whitford suggests, apparently under the influence of Professor Posner's efficiency-of-the-law hypothesis, that strict liability and negligence regimes adopt efficient standards of care. See also R. POSNER, supra note 39, at 25-191. I am very skeptical of this belief. See Priest, Punitive Damages and Enterprise Liability, S. CAL. L. REV. (forth- 
probably increased the rate of product defects. Like all scientific judgments, I must emphasize its tentative nature. I do not believe that I have proven such an effect. My data, while the best available, are admittedly incomplete and only of inferential value.

My judgment is based upon the implications of the investment theory, which provides the best explanation of the data currently available. The two major warranty theories that I examine in my article-the exploitation theory and the signal theory-explain very little despite their influence and broad acceptance. Professor Whitford's four partial theories, to my mind, explain even less. Whitford, in a concluding section, proposes to rescue his theories with statistical technique. He suggests stringing together his six theories with my investment theory, and then applying regression analysis to determine the relative importance of each. ${ }^{87}$ This confuses the variables identified by a theory with the theory itself. My theory conflicts with Whitford's theories, and the conflict cannot be reconciled by statistical manipulation. The principal purpose of scientific endeavor is to define and sharpen a theory until it conflicts with some currently accepted theory. A common, contrasting method in some social sciences is to attempt to describe some phenomenon in all of its complexity, invoking one partial theory or another as the observed phenomenon requires. ${ }^{88}$ This approach, to be sure, presents a picture that is more complete. But it dulls our critical abilities instead of sharpening them.

The conflict between Professor Whitford and me must not be smoothed over. It should define the research agenda for studies of products liability law. I am currently attempting to obtain more complete and direct data of the effects of modern products liability law, but to date no better data have been found. I challenge Professor Whitford and others to find better data as well-data sufficiently detailed to support or cast doubt on our modern theories of product warranties.

coming 1982). Even if true, the article criticizes standards under either negligence or strict liability regimes in which courts substitute their judgment for the terms of the warranty contract. Whitford's remarks seem to miss this crucial point.

87. Whitford at p. 1384.

88. Sec, e.g., Whitford, Law and the Consumer Transaction: A Case Study of the Automobile Warranty, 1968 WIS. L. REV. 1006. 


\section{The Yale Law Journal}

Volume 91, Number 7, June 1982

$\begin{array}{cc} & \begin{array}{c}\text { David Wippman } \\ \text { Editor-in-Chief }\end{array} \\ \text { Randall Kennedy } & \text { Ellen R. Porges } \\ \text { Note \& Topics Editor } & \text { Managing Editor } \\ \text { Richard Bartlett } & \text { Tim Atkeson } \\ \text { George C. Harris } & \text { Russell Hayman } \\ \text { Robert Silver } & \text { Jonathan R. Macey } \\ \text { George Wyeth } & \text { Theodore A. Paradise } \\ \text { Note Editors } & \text { Alan O. Sykes }\end{array}$

Article \& Book Review Editors

Kathleen Cully

Robert D. Gilbert

Charles Glick

Mark A. Goldberg

Candice Hoke

Jose Berrocal

Gregg Bloche

David Brodsky

Steven G. Calabresi

Lucy Cardwell

Robert Cooper, Jr.

Nicholas De Feis

Davison Douglas

Martha Duncan

George Ellard

Cynthia Estlund
Rick Levy

David R. Lewis

John Lewis

Rory K. Little

Jonathan E. Richman

Senior Editors

Steven Gunby

David Hansell

Doron Henkin

Michele Hirshman

Samuel Issacharoff

Michael Jacobs

Valerie Lambiase

Janet Langford

Noel V. Lateef

Eric Lewis

Carl Loewenson, Jr.

Meridee Moore

Editors
Alfred O. Rose

Dietrich L. Snell

Hector Torres

Lynn A. Stout

Monique Witt

John Motulsky

Gene Oshman

Richard Revesz

Robert Richman

William Rooney

Victoria Rostow

Bennett Rushkoff

Daniel Smirlock

Donald Sparks

Hubertus van der Vaart

Wendy Warring

Editorial Assistant: Liz Doyle

Business Manager: Pamela Standish

\section{Student Contributors to This Issue}

Steven G. Calabresi, A Madisonian Interpretation of the Equal Protection Doctrine

Robert D. Gilbert, Professional Obligation and the Duty to Rescue: When Must a Psychiatrist Protect His Patient's Intended Victim?

David R. Lewis, A Proposal to Restructure Sanctions Under the Occupational Safety and Health Act: The Limitations of Punishment and Culpability

Alfred O. Rose, Institutional Reform Litigation: Representation in the Remedial Process 